\section{Specificity and sensibility of primer pair in the detection of Colletotrichum gossypii var. cephalosporioides in cotton seeds by PCR technique}

\author{
Mirella Figueiró de Almeida ${ }^{1 *}$ (D) Sarah da Silva Costa ${ }^{1}$, lara Eleutéria Dias ${ }^{1}$, \\ Carolina da Silva Siqueira ${ }^{1}$, José da Cruz Machado ${ }^{1}$
}

ABSTRACT: Cotton Ramulosis (Gossypium hirsutum) is an important disease affecting cotton plantations in Brazil, and its causal agent, Colletotrichum gossypii var. cephalosporioides (Cgc), according to the Brazilian phytosanitary authority, was considered a regulated non quarantine pest. It makes this microorganism subject to standardization in seed certification programs. The current seed health testing for detecting that pathogen in seed samples does not provide reliable results for routine analysis. On this paper, attempts were made to design specific primers for detection of $\mathrm{Cgc}$ associated with cotton seed. Two primer sets were selected based on the analysis of a multiple alignment of gene's sequence encoding the glyceraldehyde 3-phosphate dehydrogenase from $\mathrm{Cgc}, \mathrm{C}$. gossypii and reference strains of the $C$. gloeosporioides species complex. The conserved sites unique to $\mathrm{Cgc}$ strains were used to design specific fragment of $140 \mathrm{bp}$. The primer specificity was confirmed by using other fungi. The primers produced a detectable band of target DNA of $\mathrm{Cgc}$ in all inoculum potentials of the pathogen artificially inoculated by the water restriction technique. The developed primer pair represents, therefore, a reliable and rapid mean to diagnose the Ramulosis agent in cotton seed.

Index terms: Colletotrichum gossypii, Colletotrichum gloeosporioides, Ramulosis, water restriction.

Especificidade e sensibilidade de um par de primer na detecção de Colletotrichum gossypii var. cephalosporioides em sementes de algodão pela técnica de PCR

RESUMO: A ramulose do algodão (Gossypium hirsutum), causada por Colletotrichum gossypii var. cephalosporioides $(\mathrm{Cgc})$, é uma doença importante que afeta as plantações de algodão no Brasil. De acordo com as autoridades fitossanitárias brasileiras, esse organismo tem sido considerado uma praga quarentenária não regulamentada, o que faz com que ela seja objeto de padronização em programas de certificação de sementes. Neste trabalho, um par de primer foi selecionado com base na análise de um alinhamento múltiplo de sequências do gene que codifica a gliceraldeído-3fosfato desidrogenase a partir de $\mathrm{Cgc}, C$. gossypii e isolados de referência representantes de outras espécies do complexo C. gloeosporioides. Uma única região conservada de Cgc foi utilizada para desenhar um par de primer específico de $140 \mathrm{pb}$. A especificidade dos primers foi confirmada pela utilização de outros fungos isolados de semente algodão. Os primers produziram uma banda detectável de DNA de $\mathrm{Cgc}$ em todos os potenciais de inóculo artificialmente inoculados pela técnica de restrição hídrica. Os primers desenvolvidos representam, portanto, um meio confiável e rápido para diagnosticar Cgc em amostras de sementes de algodão.

Termos para indexação: Colletotrichum gossypii, Colletotrichum gloeosporioides, ramulose, restrição hídrica.
Journal of Seed Science, v.42, e202042012, 2020

http://dx.doi.org/10.1590/2317$1545 v 42229530$
${ }^{*}$ Corresponding author
E-mail: mirellafa@yahoo.com.br

Received: $10 / 3 / 2019$ Accepted: 2/5/2020.

\footnotetext{
${ }^{1}$ Departamento de Fitopatologia, Universidade Federal de Lavras, Caixa Postal 3037, 37200-000 Lavras, MG, Brasil.
} 


\section{INTRODUCTION}

Ramulosis is one of the most prominent diseases in cotton (Gossypium hirsutum) in Brazil, and it is caused by Colletotrichum gossypii var. cephalosporioides A. S. Costa. This organism belongs to the Colletotrichum gloeosporioides species complex, as well as Colletotrichum gossypii South. (Cg), which causes Anthracnose in cotton (Salustiano et al., 2014).

These fungi (C. gossypii var. cephalosporioides and C. gossypii) belong to the Ascomycota phylum, having as main feature the production of conidial mass with orange color in acervuli and conidia morphologically similar (Bailey et al., 1996). Both pathogens are transmitted by seeds and cause damages in cotton plants (Silva-Mann et al., 2005; Mehta and Mehta, 2010).

Colletotrichum taxonomy was subject of extensive discussion by the variability of species classified in this genus; so, there are difficulties in the identification and separation of these organisms. Traditionally, the identification of that genus' members was based on some morphological characteristics, with emphasis on morphometry of conidia, colony color, mycelial growth rate and pathogenicity (Bailey et al., 1996; Tozze-Júnior et al., 2006). Specifically for the Colletotrichum complex associated with cotton, it is not always possible to differ what are the pathogens involved in the symptomatology of Ramulosis and Anthracnose, as well as the different degrees of aggressiveness and symptoms (Carvalho et al., 2015).

Within the seed pathology, the detection and differentiation between $C$. gossypii var. cephalosporioides and C. gossypii were carried out by using the "blotter" method, in which the assessment is based on mycelial growth habit of fungi developed in seeds after an incubation period (Tanaka et al., 1996). In this case, the high morphological similarities and isolate variability of these fungi make the results of such analysis questionable and not always consistent (Silva-Mann et al., 2002; Mehta and Mehta, 2010), determining the need to develop more accurate and reliable methods for this task.

Accuracy in identification of $C$. gossypii var. cephalosporioides and $C$. gossypii is, thus, necessary and indispensable to diagnose and control the involved diseases, as well as demand for detection methods of these fungi in seed samples on laboratory routine activities (Carvalho et al., 2015).

Molecular techniques and DNA sequence analysis were important to distinguish and identify populations of organisms at different levels. Currently, the PCR technique is used for direct detection of fungi and other organisms in association with seeds (Lee et al., 2002; Munkvold, 2009; Barrocas et al., 2012). This technology was successful in detecting, for example, Stenocarpella complex (S. maydis and S. macrospora) in maize (Romero and Wise, 2015), Fusarium oxysporum f.sp. phaseoli in bean seeds (Sousa et al., 2015), Sclerotinia sclerotiorum in soybean seeds (Botelho et al., 2015) and Corynespora cassiicola in soybean seeds (Sousa et al., 2016).

This study aimed to design specific primer pair to detect Colletotrichum gossypii var. cephalosporioides in cotton seeds and establish a protocol for safer and more sensitive sanitary analysis in the detection of this pathogen by PCR, ensuring to the cotton producers a safer quality control and providing better protection for agricultural production environments in the country.

\section{MATERIAL AND METHODS}

Isolates obtention: Colletotrichum gossypii var. cephalosporioides isolates and other fungi species were obtained from the mycological collection of the Mycology Laboratory and of the Seed Pathology Laboratory of the Universidade Federal de Lavras (UFLA), in Lavras, MG, Brazil (Table 1).

DNA extraction: genomic DNA was extracted from monosporic cultures of isolates grown on potato dextrose agar (PDA) for five days. The mycelium was scraped and homogenized in liquid nitrogen, and the extraction was performed using the Wizard ${ }^{\circledR}$ Genomic DNA purification kit (Promega, Madison, WI), according to the DNA extraction protocol recommended by the manufacturer. DNA concentrations were estimated using the NanoDrop 2000 instrument and visually in $1.2 \%$ agarose gel, by comparison of band intensity with a fragment size marker of $1 \mathrm{~kb}$ (Invitrogen). 
Table 1. Isolates of Colletotrichum gossypii var. cephalosporioides and others fungal species associated with cotton and others hosts used in the specificity test.

\begin{tabular}{|c|c|c|c|c|c|}
\hline Species & $\mathrm{CML}^{1}$ & Other code ${ }^{2}$ & Geographic origine $^{3}$ & Host & $\begin{array}{l}\text { Specific } \\
\text { Primer }^{4}\end{array}$ \\
\hline C. gossypii var. cephalosporioides & & LAPS 22 & Maracaju, MT & Gossypium hirsutum & + \\
\hline C. gossypii var. cephalosporioides & & LAPS 23 & Maracaju, MT & Gossypium hirsutum & + \\
\hline C. gossypii var. cephalosporioides & & LAPS 24 & Tangará da Serra, MT & Gossypium hirsutum & + \\
\hline C. gossypii var. cephalosporioides & & LAPS 32 & Primavera do Leste, MT & Gossypium hirsutum & + \\
\hline C. gossypii var. cephalosporioides & 2371 & LAPS 259 & Santa Helena de Goiás, GO & Gossypium hirsutum & + \\
\hline C. gossypii var. cephalosporioides & 2372 & LAPS 260 & Primavera do Leste, MT & Gossypium hirsutum & + \\
\hline C. gossypii var. cephalosporioides & 2373 & LAPS 261 & Pedra Preta, MT & Gossypium hirsutum & + \\
\hline C. gossypii var. cephalosporioides & 2374 & LAPS 263 & Primavera do Leste, MT & Gossypium hirsutum & + \\
\hline C. gossypii var. cephalosporioides & 2375 & LAPS 264 & Mineiros, GO & Gossypium hirsutum & + \\
\hline C. gossypii var. cephalosporioides & 2376 & LAPS 265 & Campo Verde, MT & Gossypium hirsutum & + \\
\hline C. gossypii var. cephalosporioides & 2377 & LAPS 266 & Primavera do Leste, MT & Gossypium hirsutum & + \\
\hline C. gossypii var. cephalosporioides & 2378 & LAPS 267 & Mineiros, GO & Gossypium hirsutum & + \\
\hline C. gossypii var. cephalosporioides & 2379 & LAPS 268 & Mineiros, GO & Gossypium hirsutum & + \\
\hline C. gossypii var. cephalosporioides & 2380 & LAPS 269 & Nova São Joaquim, MT & Gossypium hirsutum & + \\
\hline C. gossypii var. cephalosporioides & 2381 & LAPS 270 & Nova São Joaquim, MT & Gossypium hirsutum & + \\
\hline C. gossypii var. cephalosporioides & 2382 & LAPS 271 & Pedra Preta, MT & Gossypium hirsutum & + \\
\hline C. gossypii var. cephalosporioides & 2383 & LAPS 272 & Itiquira, MT & Gossypium hirsutum & + \\
\hline C. gossypii var. cephalosporioides & 2384 & LAPS 273 & Itiquira, MT & Gossypium hirsutum & + \\
\hline C. gossypii var. cephalosporioides & 2386 & LAPS 275 & Itiquira, MT & Gossypium hirsutum & + \\
\hline C. gossypii var. cephalosporioides & 2387 & LAPS 276 & Itiquira, MT & Gossypium hirsutum & + \\
\hline C. gossypii var. cephalosporioides & & LAPS 277 & Primavera do Leste, MT & Gossypium hirsutum & + \\
\hline C. gossypii var. cephalosporioides & & LAPS 392 & Primavera do Leste, MT & Gossypium hirsutum & + \\
\hline C. gossypii var. cephalosporioides & & LAPS 393 & Primavera do Leste, MT & Gossypium hirsutum & + \\
\hline C. gossypii var. cephalosporioides & & LAPS 396 & Primavera do Leste, MT & Gossypium hirsutum & + \\
\hline C. gossypii var. cephalosporioides & & LAPS 397 & Primavera do Leste, MT & Gossypium hirsutum & + \\
\hline C. gossypii var. cephalosporioides & & LAPS 398 & Primavera do Leste, MT & Gossypium hirsutum & + \\
\hline C. gossypii var. cephalosporioides & & LAPS 400 & Primavera do Leste, MT & Gossypium hirsutum & + \\
\hline C. gossypii var. cephalosporioides & & CGCUber & Uberlândia, MG & Gossypium hirsutum & + \\
\hline Colletotrichum gossypii & 2327 & CG3LEM & Luís Eduardo Magalhães, BA & Gossypium hirsutum & - \\
\hline Colletotrichum siamense sensu lato & 2884 & $\mathrm{CCJ} 73$ & Campo Grande, PB & $\begin{array}{l}\text { Anacardium } \\
\text { occidentale }\end{array}$ & - \\
\hline Colletotrichum tropicale & 2888 & CCJ105 & Fortaleza, CE & $\begin{array}{l}\text { Anacardium } \\
\text { occidentale }\end{array}$ & - \\
\hline Colletotrichum asianum & 2893 & CCJ204 & São Luís, MA & $\begin{array}{l}\text { Anacardium } \\
\text { occidentale }\end{array}$ & - \\
\hline Colletotrichum theobromicola & 2931 & MT68 & Pacajus, CE & $\begin{array}{l}\text { Anacardium } \\
\text { occidentale }\end{array}$ & - \\
\hline Colletotrichum truncatum & & LAPS133 & Rio Verde, GO & Phaseolus vulgaris & - \\
\hline Colletotrichum gloeosporioides & & CAA115/1 & Acari, MG & Annona reticulata & - \\
\hline Colletotrichum fructicola & & CAA137 & Acari, MG & Annona crassiflora & - \\
\hline
\end{tabular}


Table 1. Continuation.

\begin{tabular}{|c|c|c|c|c|c|}
\hline Species & $\mathrm{CML}^{1}$ & Other code ${ }^{2}$ & Geographic origine $^{3}$ & Host & $\begin{array}{l}\text { Specific } \\
\text { Primer }^{4}\end{array}$ \\
\hline Colletotrichum karstii & & CAA81 & Umbuzeiro, MG & Annona crassiflora & - \\
\hline Colletotrichum gigasporum & 3316 & LabioMMi3311 & Brazil & Piper aducum & - \\
\hline Aspergillus flavus & 2708 & & Montividiu, GO & $\begin{array}{l}\text { Solo (Gossypium } \\
\text { hirsutum) }\end{array}$ & - \\
\hline Aspergillus clavatus & 2734 & & Ibiá, MG & Seed (Glycine max) & - \\
\hline Aspergillus chevalieri & 2737 & & Lavras, MG & $\begin{array}{l}\text { Seed (Phaseolus } \\
\text { vulgaris) }\end{array}$ & - \\
\hline Bipolaris sorokiniana & 3315 & LabioMMi285 & São Carlos, SP & Piper aducum & - \\
\hline Curvularia sp. & & CTC15 & Pará & & - \\
\hline Alternaria alternata & 3314 & LabioMMi06 & Brazil & & - \\
\hline Diaphorte sp. & & LAPS559 & São Paulo, SP & Glycine max & - \\
\hline Phoma tarda & 716 & & Campanha, MG & Coffea arabica & - \\
\hline Phoma exígua & 940 & & Coromandel, MG & Coffea arabica & - \\
\hline Penicillium citrunum & 3310 & LabioMMi249 & Teresina, PI & & - \\
\hline Penicillium terrigenum & 1226 & & Montividiu, GO & Gossypium hirsutum & - \\
\hline $\begin{array}{l}\text { Fusarium oxysporum f. sp. } \\
\text { vasinfectum }\end{array}$ & 1119 & & Mato Grosso & Gossypium hirsutum & - \\
\hline Ascochyta sp. & 361 & & Lavras, MG & Baccharis sp. & - \\
\hline Phomopsis sp. & & FEL89 & Brazil & & - \\
\hline Clonostachys roseum & & CSO36 & Brazil & & - \\
\hline Cercospora sp. & & LAPS255 & Campo Verde, MT & Glycine max & - \\
\hline Fusarium paranaense & 1830 & & Brazil & Glycine max & - \\
\hline Didymella sp. & 193 & & Machado, MG & Coffea arabica & - \\
\hline Macrophomina sp. & & MA01 & Primavera do Leste, MT & Glycine max & - \\
\hline Corynespora cassiicola & & LAPS467 & São Paulo, SP & Glycine max & - \\
\hline Sclerotinia sp. & & LAPS242 & Uberlândia, MG & Glycine max & - \\
\hline
\end{tabular}

${ }^{1} \mathrm{CML}=$ mycological collection of the Plant Pathology Department, Universidade Federal de Lavras, Lavras, MG, Brazil.

${ }^{2}$ LAPS = mycological collection of the Seed Pathology Laboratory, Universidade Federal de Lavras, Lavras, MG, Brazil.

${ }^{2}$ LaBioMMi = Microorganisms Micromolecular Biochemistry Laboratory, Chemistry Department, Universidade Federal de São Carlos, São Carlos, SP, Brazil.

${ }^{3}$ States of Brazil: $\mathrm{BA}=$ Bahia; $\mathrm{CE}=$ Ceará; $\mathrm{GO}=$ Goiás; $\mathrm{MG}=$ Minas Gerais; $\mathrm{MA}=$ Maranhão; $\mathrm{MT}=$ Mato Grosso; $\mathrm{PB}=\mathrm{Paraíba} ; \mathrm{PI}=$ Piauí; SP = São Paulo.

${ }^{4}$ Specific primer; (+) PCR amplification; (-) no PCR amplification.

Development of specific primers for detection and identification of C. gossypii var. cephalosporioides: alignments generated from the sequences of the work of Salustiano et al. (2014), using ClustalW implemented by MEGA5 (Tamura et al., 2011), were obtained for the partial DNA of glyceraldehyde 3-phosphate dehydrogenase gene (GAPDH) of Cgc isolates and other species from the $C$. gloesporioides species complex. Unique sites in the sequences of the Ramulosis' etiologic agent were identified and used to design species-specific primers. The primer sequences were compared using the BLAST program in order to verify its homology with sequences previously deposited in GenBank (https:// www.ncbi.nlm.nih.gov/) (Table 2). The developed primer pair was analyzed for performance characteristics such as hairpin structure, potential self-dimer formation and stability of 3 termini, using OligoAnalyzer 3.1 integrated platform (https://www.idtdna.com/analyzer/Applications/OligoAnalyzer/). The primers' synthesis was performed by Sigma- 
Aldrich Brazil LTD. The genomic material isolated from C. gossypii var. cephalosporioides was subjected to PCR analysis.

Determining primer specificity: the specificity of the primer pair was tested by PCR amplification of genomic DNA of 28 Cgc's isolates, ten isolates of Colletotrichum's other species and 21 isolates of other fungal species, which were reported in cotton seed and other host (Table 1). PCR was performed using $25 \mu \mathrm{L}$ mix for PCR OneTaq (BioLabs), containing $10 \mathrm{pmol}$ of forward and reverse primers and DNA $10 \mathrm{ng}$. The DNA amplification was performed under the following cycle conditions: $94{ }^{\circ} \mathrm{C}$ for four minutes (initial denaturation), $94{ }^{\circ} \mathrm{C}$ for 45 seconds (denaturation), $65{ }^{\circ} \mathrm{C}$ for 45 seconds (annealing), $72{ }^{\circ} \mathrm{C}$ for one minute (extension), and 34 cycles of $72{ }^{\circ} \mathrm{C}$ for ten minutes (final extension). To separate PCR products, an aliquot of $10 \mu \mathrm{L}$ was used on $1.2 \%$ agarose gel, stained with GelRed ${ }^{\circledR}$ (Biotium ${ }^{\circledR}$, Hayward, 95 CA, USA). The PCR products were observed in UV transilluminator, L-Pix HE equipament (Loccus Biotechnology, Brazil). Before using the specific primers, a PCR reaction was performed using universal GDF primers GDF (5' - GCCGTCAACGACCCCTTCATTGA$3^{\prime}$ ) and universal GDR primers GDR (5'- GGGTGGAGTCGTACTTGAGCATGT- 3') (Templeton et al., 1992), with the genomic DNA of all species used in this study to test if the genomic DNA was adequate for PCR amplification. The experiments were repeated at least two times.

Sensivity evaluation of primers developed in seed samples: to evaluate the sensitivity of PCR reaction using primer pair, cotton seed with different infestation level inoculated with C. gossypii var. cephalosporioides was used, and a four-hundred-seed sample were prepared by mixing the artificially inoculated seeds with healthy seeds generating three infestation level $(100 \%, 10 \%$ and $1 \%)$ per inoculum. For each infestation level of seeds, the test was performed in four replicates, and the experiment was repeated twice.

Table 2. GenBank accession numbers of Colletotrichum gossypii var. cephalosporioides and other species from the $C$. gloesporioides species complex used to obtain specific primer pair to Cgc.

\begin{tabular}{|c|c|c|c|c|c|}
\hline Species & $\mathrm{CML}^{1}$ & Other code ${ }^{2}$ & Host & Origin $^{3}$ & $\begin{array}{c}\text { GenBank } \\
\text { number }\end{array}$ \\
\hline C. gossypii var. cephalosporioides & 2373 & LAPS 261 & Gossypium hirsutum & Pedra Preta, MT & $J \times 847009$ \\
\hline C. gossypii var. cephalosporioides & 2379 & LAPS 268 & Gossypium hirsutum & Mineiros, GO & JX847010 \\
\hline C. gossypii var. cephalosporioides & 2384 & LAPS 273 & Gossypium hirsutum & Itiquira, MT & JX847011 \\
\hline C. gossypii var. cephalosporioides & 2388 & IAC 13350 & Gossypium hirsutum & Piracicaba, SP & JX847012 \\
\hline C. gossypii var. cephalosporioides & 2389 & IAC 12405 & Gossypium hirsutum & Ituverava, SP & $J X 847013$ \\
\hline Colletotrichum gossypii & 2324 & IAC 1025 & Gossypium hirsutum & Campinas, SP & JX847014 \\
\hline Colletotrichum gossypii & 2325 & CG 1 LEM & Gossypium hirsutum & $\begin{array}{l}\text { Luis Eduardo Magalhães, } \\
\text { BA }\end{array}$ & JX847015 \\
\hline Colletotrichum gossypii & 2327 & CG 3 LEM & Gossypium hirsutum & $\begin{array}{l}\text { Luis Eduardo Magalhães, } \\
\text { BA }\end{array}$ & JX847016 \\
\hline C. kahawae subsp. kahawae & & ICMP 17905 & Coffea arabica & Kenya & JX010012 \\
\hline Colletotrichum gloeosporioides & & IMI 356878 & Citrus sinensis & Italy & JX010056 \\
\hline Colletotrichum fructicola & & ICMP 18581 & Coffea arabica & Thailand & JX010033 \\
\hline Colletotrichum siamense & & ICMP 18578 & Coffea arabica & Thailand & JX009924 \\
\hline Colletotrichum asianum & & ICMP 18580 & Coffea arabica & Thailand & JX010053 \\
\hline Colletotrichum theobromicola & & ICMP 17958 & Stylosanthes guianensis & Australia & JX009948 \\
\hline Colletotrichum boninense & & CBS 112115 & Leucospermum sp. & Australia & JQ005247 \\
\hline
\end{tabular}

${ }^{1} \mathrm{CML}=$ mycological collection of the Plant Pathology Department, Universidade Federal de Lavras, Lavras, MG, Brazil. ${ }^{2}$ LAPS = mycological collection of the Seed Pathology Laboratory, Universidade Federal de Lavras, Lavras, MG, Brazil.

$\mathrm{IAC}=$ Campinas Agronomic Institute, Campinas, SP, Brazil.

ICMP = International Collection of Microorganisms from Plants, New Zeland.

$\mathrm{CBS}=$ Centralalbureau voor Schimmelcultures, Utrecht, The Netherlands.

${ }^{3}$ States of Brazil: BA = Bahia; GO = Goiás; MT = Mato Grosso; SP = São Paulo. 
Seed inoculation: cotton seeds CV delta opal susceptible to the Ramulosis' etiologic agent were disinfected in 70\% alcohol for one minute, followed by $1 \%$ of sodium hypochlorite solution for two minutes, then washed four times with autoclaved distilled water. The sterilized seeds were arranged in trays where they remained for 24 hours at room temperature to complete drying. After drying, it was used physiological conditioning method or water restriction for seed inoculation (Machado et al., 2012; Barrocas et al., 2014).

Then, the seeds were artificially inoculated with the C. gossypii var. cephalosporioides strain CML2374 that growed in petri dishes with fifteen $\mathrm{cm}$ diameter containing PDA medium, modified by the addition of manitol adjusted with water potential of -1.0 MPa, as SPPM Software (computer program that relates solute potencial to solution composition). A sequence of data was generated over temperature, concentration, or potential ranges by specifying an initial value (Michel and Radcliffe, 1995), remaining seven days in BOD at $25^{\circ} \mathrm{C}$ with a photoperiod of twelve hours. The seeds were placed in a single layer on the fungus colony, where they remained for 24 and 48 hours, being removed and placed in sterilized trays and dried in a laminar flow chamber for 24 hours. As controls, seeds were used without the fungus and with incubation in substrate with water restriction.

DNA extraction of seed samples: the inoculated seed samples were macerated in mill (IKA ${ }^{\circ} \mathrm{A} 11$ analytical basic mill) with liquid nitrogen to obtain a thin powder. Samples with $0.04 \mathrm{~g}$ of this powder were placed in $1.5 \mathrm{~mL}$ microtubes in four replicates. The extraction was carried out with the use of Wizard ${ }^{\circledR}$ Genomic DNA purification kit (Promega, Madison, WI), according to the DNA extraction protocol recommended by the manufacturer. The PCR reaction and the cycle conditions were the same described for the specificity of the primer pair.

\section{RESULTS AND DISCUSSION}

Colletotrichum gossypii var. cephalosporioides specific primers designed from the GAPDH gene had the following sequences: CGC1F (5'- CAG ACT ACA AGG CCA ACG C- 3') and CGC1R (5'- GAG TCG TAC TTG AGC ATG TAG- 3'). This primer pair amplifies a fragment of $140 \mathrm{bp}$. This primers' pair specifically amplified DNA of only its respective target, $\mathrm{Cgc}$, in all reactions (Figure $1 \mathrm{~A}$ ). The primers did not cross-react with DNA of any other Colletotrichum species or other fungal species tested (Figure $1 \mathrm{~B}$ and Table 1 ).

The sensitivity of the primers' pair may be considered high due to their capacity of detecting the pathogen in seed samples with minimal incidence of $1 \%$, which was the limit used in this study. In the controls, there was no amplification of the genomic DNA from the causative agent of cotton Ramulosis (Figure 2).

A PCR-based diagnostic assay using specific primers derived from the gene encoding the glyceraldehyde 3-phosphate dehydrogenase was developed for the Ramulosis' causal agent from cotton, C. gossypii var. cephalosporioides. Furthermore, the primers were able to detect the pathogen in artificially infested cotton seeds.

The PCR products obtained from the seeds showed characteristic bands, as observed in the pathogen's DNA amplification in pure cultures. Thus, it was evident that the primer pair was effective in detecting the Ramulosis' etiological agent in artificially infested cotton seeds, indicating no false positive result for contamination. These primer pair allowed the amplification of the genomic DNA samples from the $C$. gossypii var. cephalosporioides tested, being effective in detection of fungal incidences from 1 to $100 \%$ at different inoculum potential tested.

In a study conducted by Guimarães et al. (2017), the pair of primers designed and described was used to quantify $C$. gossypii var. cephalosporioides in artificially inoculated cotton seeds by CPCR and $\mathrm{qPCR}$ techniques. The results showed that the primers used were reliable. Primers showed linearity in the standard curve generated by qPCR technique at each dilution level of Cgc DNA extracted from pure culture. The quantification of the inoculum potential by qPCR was $1.44 \mathrm{pg} / \mu \mathrm{L}$ DNA at P24, which increases to $6.89 \mathrm{pg} / \mu \mathrm{L}$ at P48 and $24.5 \mathrm{pg} / \mu \mathrm{L}$ at P96. The authors concluded that there was proportionality between fungal DNA, inoculum potential, effects on germination and seed vigor.

For other pathosystems, the sensitivity in detecting seeds' pathogens is variable. For example, in a study conducted by Barrocas et al. (2012), Sternocarpella was detected in maize seeds infected with minimal incidence of $2 \%$ in the studied samples. In a study conducted by Sousa et al. (2015), Fusarium oxysporum f. sp. phaseoli fungus was detected 
in lower levels of infection, and $0.25 \%$ incidence in beans seeds. One possibility of increasing the PCR sensitivity is prior incubation in favorable conditions for the development of fungi in seeds. Other example, CPCR and qPCR techniques were effective in detecting Colletotrichum lindemuthianum in beans seeds. It was possible using cPCR to detect the fungus in seed samples with $10 \%$ of incidence and with $0.25 \%$ incidence by qPCR technique (Gadaga et al., 2018).

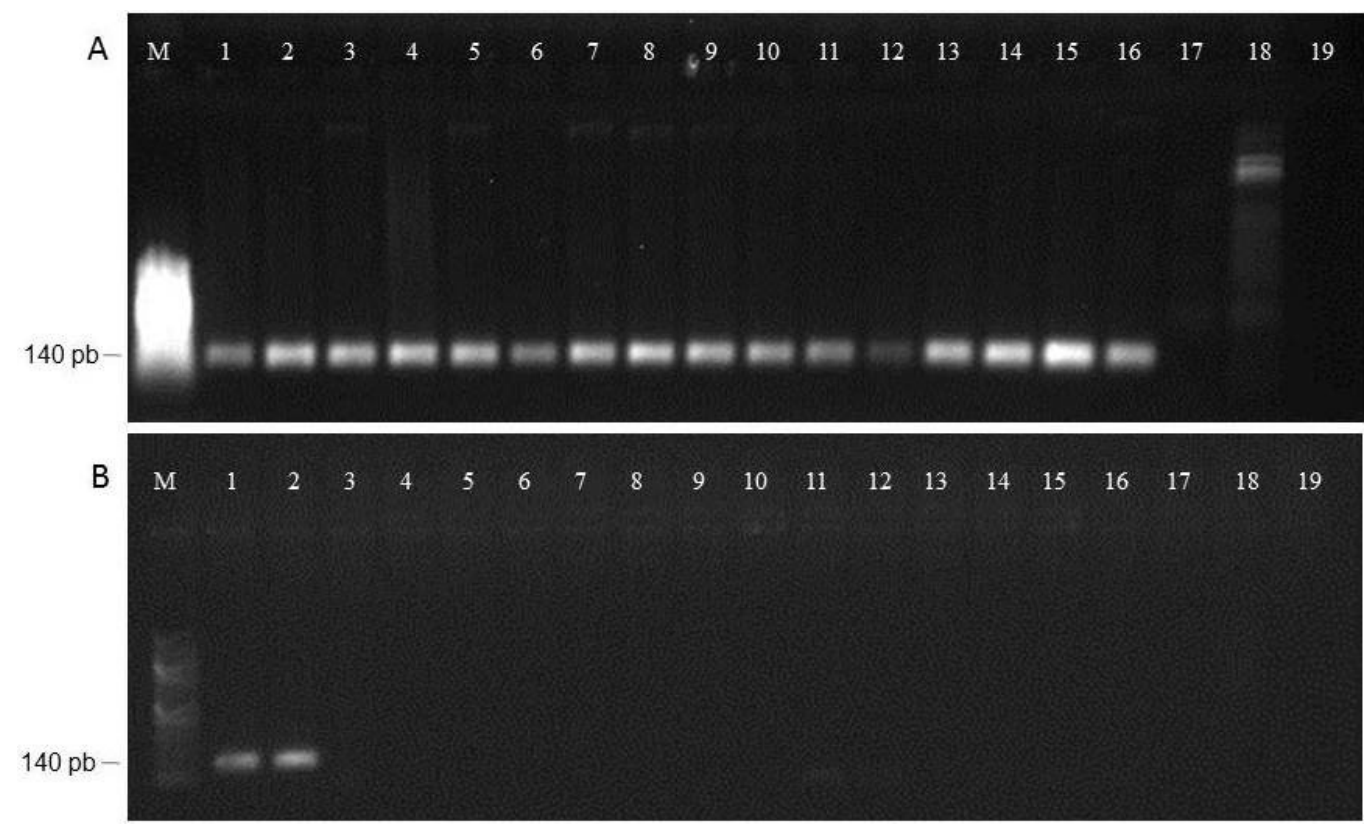

A: lane M-100-bp marker (Axygen); lanes 1-16 (positive control): Colletotrichum gossypii var. cephalosporioides (LAPS22, LAPS23, LAPS32, CML2371, CML2372, CML2373, CML2374, CML2375, CML2376, CML2377, CML2378, CML2381, CML2382, CML2383, CML2384, CML2386); lanes 17-19 (negative control): lane 17: CML1119 (Fusarium oxysporum f. sp. vasinfectum); lane 18: MA01 (Macrophomina sp.); lane 19: water. B: lane M-100-bp marker (Axygen); lanes 1 and 2 (positive control): C. gossypii var. cephalosporioides (CML2374 e 2379); lanes 3-19 (negative control): lane 3: C. gossypii (CML2327); 4-12: other species of Colletotrichum (CML2884, CML2888, CML2893, CML2931, LAPS133, CAA115/1, CAA137, CAA81, CML3316); 13-19: other fungal species (CML2708, CML2734, CML2737, CML3315, CTC15, CML3314, LAPS559).

Figure 1. Specificity test of conventional PCR with primer pair CGC1F/ CGC1R.

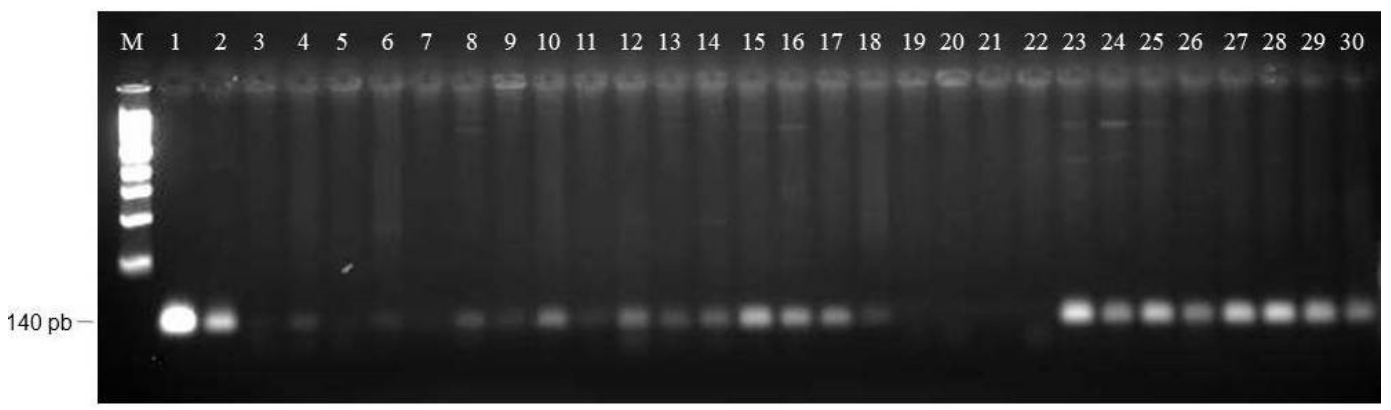

Lane M: 50kb marker; lanes 1 and 2 - Cgc - CML2384 and 2374 isolates; lanes 3 to 6: $1 \%$ infection with seeds inoculated for 24 hours; lanes 7 to $10: 10 \%$ infection with seeds inoculated for 24 hours; lanes 11 to $14: 1 \%$ infection with seeds inoculated for 48 hours; lanes 15 to 18 : $10 \%$ infection with seeds inoculated for 48 hours; lanes 19 to 22: control without fungus; lanes 23 to 26 : $100 \%$ seeds infected with inoculation of 24 hours; lanes 27 to $30: 100 \%$ seeds infected with inoculation of 48 hours.

Figure 2. Sensitivity test of conventional PCR with primer pair CGC1F/ CGC1R in the detection of Colletotrichum gossypii var. cephalosporioides in samples of cotton seeds with different infection levels. 


\section{CONCLUSIONS}

The results of this study, which complement previous work done by the pathologist group involved in this project in order to detect the causal agent of cotton Ramulosis in seed samples, meet a long-year demand from seed producers in Brazil. This technology enables a sanitary quality control of cotton seeds with greater accuracy and speed, making health analysis of seeds, which is viable and extremely important for the cotton producers.

It is also important to point out that, in practical terms, the health test protocol for the detection of $C$. gossypii var. cephalosporioides in cotton seed samples for quality certification programs can be made by implementing a health test by two methods, a molecular and a biological. In this case, samples would be initially subjected to PCR and subsequently applying the blotter test, as it was done by the current Rules for Seed Testing (Brasil, 2009a, b) for samples that had positive results in molecular testing. It is understood that combining these two methods makes the diagnosis of Ramulosis' agent in cotton seed samples safer and feasible from an operational point of view on health routine analytical laboratories.

\section{ACKNOWLEDGEMENTS}

The authors thank the Conselho Nacional de Desenvolvimento Cientifico e Tecnológico (CNPq) for providing the scholarship for the first author. To the CNPq, the Coordenação de Aperfeiçoamento de Pessoal de Nível Superior (CAPES) and the Fundação de Amparo à Pesquisa do Estado de Minas Gerais (FAPEMIG) for funding and supporting for research.

\section{REFERENCES}

BRASIL. Ministério da Agricultura, Pecuária e Abastecimento. Manual de análise sanitária de sementes. Ministério da Agricultura, Pecuária e Abastecimento. Secretaria de Defesa Agropecuária. Brasília: MAPA/ACS, 2009a. 200p. http://www.agricultura.gov.br/ assuntos/insumos-agropecuarios/insumos-agricolas/sementes-e-mudas/publicacoes-sementes-e-mudas/manual-de-analisesanitaria-de-sementes/view

BRASIL. Ministério da Agricultura, Pecuária e Abastecimento. Regras para análise de sementes. Ministério da Agricultura, Pecuária e Abastecimento. Secretaria de Defesa Agropecuária. Brasília: MAPA/ACS, 2009b. 395p. http:// www.agricultura.gov.br/arq_editor/ file/2946_regras_analise_sementes.pdf

BAILEY, J.A; NASH, C.; MORGAN, L.W.; O'CONNELL, R.J.; TEBEEST, D.O. Molecular taxonomy of Colletotrichum species causing Anthracnose on the Malvaceae. Phytopathology, v.86, p.1076-1083, 1996. https://www.apsnet.org/publications/phytopathology/ backissues/Documents/1996Articles/Phyto86n10_1076.PDF

BARROCAS, E.N.; MACHADO, J.C.; ALMEIDA, M.F.; BOTELHO, L.S.; VON PINHO, E.V.R. Sensibility of the PCR technique in the detection of Stenocarpella sp. associated to maize seeds. Revista Brasileira de Sementes, v.34, n.2, p.218-224, 2012. http://www.scielo.br/ $\mathrm{pdf} / \mathrm{rbs} / \mathrm{v} 34 \mathrm{n} 2 / 05 . \mathrm{pdf}$

BARROCAS, E.N.; MACHADO, J.C.; ALVES, M.C.; CORREA, C.L. Desempenho de sementes de algodão submetidas à deficiência hídrica e presença de Colletotrichum gossypii var. cephalosporioides. Bioscience Journal, v.30, n.2, p.421-428, 2014. http://www.seer.ufu. br/index.php/biosciencejournal/article/view/17993/13757

BOTELHO, L.S.; BARROCAS, E.N.; MACHADO, J.C.; MARTINS, R.S. Detection of Sclerotinia sclerotiorum in soybean seeds by conventional and quantitative PCR techniques. Journal of Seed Science, v.37, n.1, p.55-62, 2015. http://dx.doi.org/10.1590/2317$1545 \mathrm{v} 37 \mathrm{n} 1141460$

CARVALHO, E.M.; FIGUEIRA, A.R.; MACHADO, J.C.; ARAÚJO, D.V.; MACHADO, C.F. Variability of seed-borne Colletotrichum strains in cotton based on its1 and its2 ribossomal genes analysis. Bioscience Journal, v.31, n.3, p.691-700, 2015. https://doi.org/10.14393/ BJ-v31n3a2015-23126

GADAGA, S.J.C.; SIQUEIRA, C.S.; MACHADO, J.C. Molecular detection of Colletotrichum lindemuthianum in bean seed samples. Journal of Seed Science, v.40, n.4, p.370-377, 2018. http://dx.doi.org/10.1590/2317-1545v40n4192761 
GUIMARÃES, M.R.F.; SIQUEIRA, C.S.; MACHADO, J.C.; FRANÇA, S.K.S.; GUIMARÃES, G.C. Evaluation of inoculum potential of pathogens in seeds: relation to physiological quality and DNA quantification by qPCR. Journal of Seed Science, v.39, n.3, p.224-233, 2017. http://www.scielo.br/pdf/jss/v39n3/2317-1545-jss-39-03-00224.pdf

LEE, H.K.; TEWARI, J.P.; TURKINGTON, T.K. Quantification of seedborne infection by Rhinchosporium secalis in barley using competitive PCR. Plant Pathology, v.51, p.217-224, 2002. https://bsppjournals.onlinelibrary.wiley.com/doi/pdf/10.1046/j.13653059.2002.00685.x

MACHADO, J.C.; BARROCAS, E.N.; COSTA, L.N.; GUIMARÃES, R.M.; MACHADO, C. Uso da técnica de restrição hídrica ou condicionamento osmótico em patologia de sementes. Revisão Anual de Patologia de Plantas, v.20, p.37-63, 2012.

MEHTA, Y.R.; MEHTA, A. Variabilidade genética entre isolados de Colletotrichum gossypii do algodoeiro. Summa Phytopathologica, v.36, n.1, p.40-44, 2010. http://www.scielo.br/pdf/sp/v36n1/07.pdf

MICHEL, B.E.; RADCLIFFE, D.A. Computer program relating solute potencial to solution composition for five solutes. Agronomy Journal, v.87, p.131-136, 1995.

MUNKVOLD, G.P. Seed pathology progress in academia and industry. Annual Review of Phytopathology, v.47, p.285-311, 2009. https://doi.org/10.1146/annurev-phyto-080508-081916

ROMERO, M.P.; WISE, K.A. Development of molecular assays for detection of Stenocarpella maydis and Stenocarpella macrospora in corn. Plant Disease, v.99, p.761-769, 2015. http://apsjournals.apsnet.org/doi/pdf/10.1094/PDIS-09-14-0917-RE

SALUSTIANO, M.E.; RONDON, M.N.; ABREU, L.M.; COSTA, S.S.; MACHADO, J.C.; PFENNING, L.H. The etiological agent of cotton Ramulosis represents a single phylogenetic lineage within the Colletotrichum gloeosporioides species complex. Tropical Plant Pathology, v.39, n.5, p.357-367, 2014. http://www.scielo.br/pdf/tpp/v39n5/v39n5a02.pdf

SILVA-MANN, R.; SALGADO, K.C.C.; VIEIRA, M.G.G.C.; MACHADO, J.C. Variabilidade genética de isolados do complexo Colletotrichum associados a sementes de algodoeiro, por meio de técnicas moleculares e inoculação em plantas. Fitopatologia Brasileira, v.27, n.1, p.27-32, 2002. http://www.scielo.br/pdf/fb/v27n1/8464.pdf

SILVA-MANN, R.; VIEIRA, M.G.G.C.; MACHADO, J.C.; BERNARDINO-FILHO, J.R.; SALGADO, K.C.C.; STEVENS, M.R. AFLP markerS differentiate Colletotrichum gossypii from C. gossypii var. cephalosporioides. Fitopatologia Brasileira, v.30, n.2, p.169-172, 2005. http://www.scielo.br/pdf/fb/v30n2/a11v30n2.pdf

SOUSA, M.V.; SIQUEIRA, C.S.; MACHADO, J.C. Conventional PCR for detection of Corynespora cassiicola in soybean seeds. Journal of Seed Science, v.38, n.2, p.85-91, 2016. http://www.scielo.br/pdf/jss/v38n2/2317-1545-jss-v38n2152049.pdf

SOUSA, M.V.; MACHADO, J.C.; SIMMONS, H.E.; MUNKVOLD, G.P. Real-time quantitative PCR assays for the rapid detection and quantification of Fusarium oxysporum f. sp. phaseoli in Phaseolus vulgaris (common bean) seeds. Plant Pathology, v.64, p.478-488, 2015. https://bsppjournals.onlinelibrary.wiley.com/doi/epdf/10.1111/ppa.12257

TAMURA, K.; PETERSON, D.; PETERSON, N.; STECHER, G.; NEI, M.; KUMAR, S. MEGA5: molecular evolutionary genetics analysis using maximum likelihood, evolutionary distance and maximum parsimony methods. Molecular Biology and Evolution, v.28, n.10, p.2731-2739, 2011. https://www.ncbi.nlm.nih.gov/pmc/articles/PMC3203626/pdf/msr121.pdf

TANAKA, M.A.S.; MENTEN, J.O.M.; MACHADO, J.C. Hábito de crescimento de Colletotrichum gossypii e C. gossypii var. cephalosporioides em sementes de algodoeiro. Bragantia, v.55, n.1, p.95-104, 1996. http://www.scielo.br/pdf/brag/v55n1/11.pdf

TEMPLETON, M.D.; RIKKERINK, E.H.A.; SOLON, S.L.; CROWHURT, R.N. Cloning and molecular characterization the glyceraldehyde-3phosphate dehydrogenase-encoding gene and cDNA from the plant pathogenic fungus Glomerella cingulata. Gene, v.122, n.1, p.225-230, 1992. https://doi.org/10.1016/0378-1119(92)90055-T

TOZZE-JÚNIOR, H.J.; BUENO, C.R.N.C.; MASSOLA-JÚNIOR, N.S. Caracterização morfológica e molecular de isolados de Colletotrichum spp. de hortaliças solanáceas. Summa Phytopathologica, v.32, n.1, p.71-79, 2006. http://www.scielo.br/pdf/sp/v32n1/v32n1a11.pdf 